\title{
The Selected Problems of Public Transport Organization Using Mathematical Tools on the Example of Poland
}

\author{
Piotr Gołębiowski, Jolanta Żak, Piotr Kisielewski
}

\begin{abstract}
Public transport plays an increasingly important role in satisfying the transport needs. Travellers' requirements regarding the quality of services are increasing. In addition to passenger comfort, other parameters are important (timetable and the state of transport infrastructure). Therefore, methods that determine the appropriate organization of public transport for an area should be sought. The purpose of the article is to present the most commonly used optimization methods and tools that have been applied to the chosen problems of organization of public transport mainly in Poland (described in the articles of mainly Polish scientists), but against the background of global research. The article characterizes the functioning of public transport in Poland. The selected problems of public transport functioning, which can be solved by using optimization methods and tools were discussed. The chosen methods that were used to formulate and solve the identified problems were indicated. The effects of this article will form part of the work on the POIR.01.01.01-00-0970/17-00 project "IT system for computer-aided public transport planning" financed by the National Centre for Research and Development.
\end{abstract}

Keywords: optimization organization of public transport; public transport

\section{INTRODUCTION}

Every year, public transport plays an increasingly important role in meeting the transport needs of the population. The main factor, which causes a rise in its popularity is an increase of the ecological awareness of potential travellers, which translates into an increased concern for the natural environment. People leave their vehicles at home and choose public transport, which reduces the negative impact of transport on the environment. The second factor that influences the increasing popularity of public transport is its systematically increasing quality. Thanks to the financial resources from the European Union, older vehicles are systematically replaced with newer and more ecological ones, which attracts people.

However, travellers' requirements in shaping the quality of services provided by public transport are increasing [1-8]. In addition to passenger comfort, other parameters are extremely important. They are related to the timetable and the state of transport infrastructure. It is mainly about the frequency of travel, travel time and availability of stops. To meet these requirements, it is necessary to have the right number of vehicles that will be sufficiently capacious and to employ the right number of people who will service these vehicles. This is due to the need to have adequate financial resources for transport service companies. Obtaining the best solution that reconciles the needs of all interested parties will enable the obtaining of an appropriate organization of public transport.

Therefore, methods that will allow to determine the appropriate organization of public transport for a specific area should be sought. This organization should make it possible to meet the needs of all stakeholder groups - mainly passengers, with the minimum costs associated with it by the transport organizer. Moreover, the organization's project should enable the implementation of the concept of sustainable development, i.e. maintaining an appropriate balance between the society, the environment, and economic aspects. The organization of transport can be introduced in various ways - among others, manually or by using specialized tools with an optimization engine.

The purpose of the article is to present the most commonly used optimization methods and tools that have been applied to the chosen problems of the organization of public transport mainly in Poland (described in the articles of mainly Polish scientists), but against the background of global research. The article characterizes the functioning of public transport in Poland. The selected problems of public transport functioning, which can be solved by using the optimization methods and tools were discussed. The chosen methods that were used to formulate and solve the identified problems were indicated. The effects of this article will constitute an element of work on the project POIR.01.01.0100-0970/17-00 "Computer system for computer aided planning of public transport" financed by the National Centre for Research and Development. The project is implemented by the Faculty of Transport of the Warsaw University of Technology at the request of the DPK System Consulting.

\section{FUNCTIONING OF PUBLIC TRANSPORT IN POLAND}

The purpose of this chapter is to present problems related to the organization of public transport on the example of Poland, which can be solved by using optimization tools. The content of the chapter additionally presents the specific conditions of the functioning of public transport in Poland.

Public transport (PTZ) can be defined as publicly available regular passenger transport carried out at specific intervals and on a specific communication line, communication lines or a communication network [9]. Therefore, this transport must be equally accessible to all who would like to use it. Moreover, it should be carried out according to a fixed plan, in a repetitive manner at strictly defined or equal intervals [10]. It should be noted that in the statutory definition, a part of the concept of regularity is included later in it. Furthermore, there is a definition of the area for the implementation of public transport, i.e. a communication line or communication network. Hence, 
this area is defined as a series or set of routes of public roads together with marked communication points where people exchange takes place.

Public transport should operate according to the principles of competitiveness. For this reason, it is necessary to conclude an appropriate contract (Contract for the provision of public transport services [9]) with its organizer. The role of PTZ organizer is played by a local government unit adequate to the range of transport - including commune, district, or province. The tasks of the organizer of public transport include [9] development planning, organization, and management of PTZ. It should also be noted that organized transport should consider the concept of sustainable development. Public transport is carried out by the PTZ operator, who must have the appropriate authorizations to perform it. If the entity does not provide public services, then it may perform transport services after reporting the transport [9].

Public transport should be implemented based on a plan for sustainable development of public transport, which is commonly called a transport plan. It is developed by PTZ organizing units, with the subordinate unit having to include in its document the assumptions of the master unit plan. The transport plan specifies [9]:

- the communication network,

- transport needs assessment and forecasts,

- expected financing of transport services,

- preferences regarding the choice of the means of transport,

- rules for the organization of the transport market,

- the desired standard of transport services,

- expected organization of the passenger information system,

- communication lines served by electric vehicles or vehicles powered by natural gas,

- the location of the natural gas station and electric vehicle charging infrastructure together with the places of connection to the distribution network.

The transport plan should include [9]:

- the spatial development status,

- the socio-economic situation of the area,

- environmental impact of transport,

- the need for a sustainable development of public transport, the needs of disabled persons and persons with reduced mobility, in the field of transport services,

- needs arising from the direction of the state policy in the field of communication lines in inter-voivodship and international passenger transport,

- profitability of communication lines.

Organizing public transport can be considered from two points of view - the transport organizer and the transport operator. Organizing from the first point of view (PTZ organizer) involves, among others [9]:

- the research and analysis of transport needs, considering the needs of disabled persons and persons with reduced mobility,
- taking actions to implement the transport plan or update it,

- ensuring appropriate conditions for the operation of PTZ (in terms of stops, stations, and integrated interchanges including from the area of the tariff-ticket and information system),

- determining the method of marking the means of transport,

- setting rates for using public transport stops and stations,

- preparing and conducting proceedings leading to the conclusion of a contract for the provision of public transport services and its conclusion,

- setting transport charges and other charges for the service provided by the operator in the field of public transport,

- determining the method of ticket distribution for the service provided by the operator in the field of public transport.

Organizing from a second point of view (PTZ operator) involves, among others (based on [11]):

- delineating the routes of communication lines together with an indication of the stops where people will be exchanged,

- setting terms of riding for individual communication lines,

- determining travel times,

- determining the frequency of running on the communication line,

- setting communication routes (timetables),

- shaping transport tasks for vehicles and drivers,

- the selection of vehicles' types to carry out transport tasks,

- handling and operation of owned vehicles.

\section{SELECTED OPTIMIZATION ASPECTS OF THE FUNCTIONING OF PUBLIC TRANSPORT}

There are many aspects when optimizing public transport. In the literature written by Polish scientists, several research areas can be distinguished.

The first research area concerns how to deal with problems. Public transport can be considered by using the system theory from two points of view. The first point of view is to consider it as a static system. The state valid at a given moment is then analysed. The second point of view is considering it as a dynamic system. The specific state of the system is then not analysed, but the changes that occur in the system under the influence of time. We are then dealing with a transport process. There are many methods of testing transport processes - including using the process phase network method [12].

The second research area concerns the problem of shaping the transport offer in public transport, which is extremely important. Communication lines should be routed in such a way as to handle the largest possible number of people directly. It is therefore reasonable to study new methods for routing vehicles on the network [13-15]. 
The third research area concerns mobility. The participation of public transport in providing mobility to city users is also an important aspect $[16,17]$.

An important optimization problem related to public transport is the search for the best solution in the scope of the interval synchronization of timetables in municipal public transport [18-20]. Therefore, work is being done to ensure that subsequent communication lines depart from a given stop at a specified time interval, rather than in a group. Additionally, work is underway to optimize the timetables and circulation (cycles) of trains in railway transport [21-23]. A proper assignment of train sets [24], and buses to tasks [25] is also sought.

An important research trend related to public transport is also the choice of the means of transport for travel. This can be done by using both one criterion and multiple criteria [26]. Optimization problems in transport also apply to the optimization of depot location in each area [27]. This problem can be combined with the simultaneous determination of the routes of communication lines [28]. A large group of problems concerns the proper flow of passenger information [29].

The occurrence of a problem that can be repaired by using optimization tools should be properly diagnosed. It is possible to use quality science - qualitology $[8,30,31]$ or the multi-criteria assessment method [32, 33]. For quality assessment, it is proposed to use time savings, among other methods [34].

To summarize, we have six research areas. Their specification is related to the scope of work on the POIR.01.01.01-00-0070/17-00 project Computer system for computer aided planning of public transport financed by the National Centre for Research and Development.

Various IT tools are used to analyse optimization problems. One of the groups are simulation models [35]. They are used, among others for testing the punctuality of public transport buses [36, 37], analysing the operation of selected communication nodes $[38,39]$, optimizing the number of vehicles serving a given region [40], and individual segments of transport needs [41]. It is also important to organize traffic in such a way that time losses incurred by public transport vehicles are as low as possible [42]. An important application of simulation models is motion modelling by using specialized tools [32]. You can analyse both the current situation [43] and the possibilities of developing the transport system [44, 45]. In simulation models, it is important to properly divide transport tasks [46]. There are many dilemmas associated with traffic modelling and significant mistakes can be made [47].

For the needs of solving problems of public transport organization, IT tools are being built that allow solving optimization problems [48, 49, 50, 51].

The use of mathematical tools for the problem of the functioning of public transport is also related to the scope of work on the POIR.01.01.01-00-0070/17-00 project Computer system for computer aided planning of public transport.

\section{SELECTED OPTIMIZATION METHODS FOR THE FUNCTIONING OF PUBLIC TRANSPORT DESCRIBED IN THE ENGLISH-LANGUAGE LITERATURE}

The main optimization problem related to the subject of the POIR.01.01.01-00-0970/17-00 IT system for computeraided public transport planning is the allocation of vehicles for tasks and the allocation of teams for tasks. The issue of work planning in the context of public transport in literature is classified from the point of view of problems regarding work scheduling. The following issues have been distinguished in the English-language literature [52]:

- Crew Scheduling [53],

- Tour Scheduling [54],

- Shift Scheduling [55],

- Days-Off Scheduling [56],

- Workforce Planning [57],

- Crew Rostering [58],

- Cyclic Roster [59],

- Demand Modelling (Flexible Demand, Task-Based Demand [60], Shift Demand [61]),

- Task Assignment [37, 62],

- Shift Assignment [63],

- Roster Assignment [64],

- Other Classifications.

The above-mentioned problems have been ranked according to their popularity. Popularity should be understood as the number of articles about transport in which a given method was used. Researchers used the following methods to solve them (also ranked from the most popular to the least popular, popularity should be understood the same as above) [52]:

- Integer Programming,

- Constructive Heuristic [65],

- Set Partitioning,

- Set Covering,

- Column Generation,

- Constraint Logic Programming,

- Simple Local Search,

- Network Flow,

- Matching,

- Linear Programming,

- Lagrange Relaxation,

- Queueing Theory,

- Simulation,

- Branch-and-Price,

- Genetic Algorithms,

- Mathematical Programming,

- Simulated Annealing,

- Goal Programming,

- Dynamic Programming,

- Tabu Search,

- Expert Systems,

- Branch-and-Bound,

- Enumeration,

- Other Metaheuristics,

- Branch-and-Cut,

- Iterated Randomised Construction,

- Evolution. 


\section{SUMMARY AND CONCLUSIONS}

The purpose of the article was to present the most commonly used optimization methods and tools that have been applied to the chosen problems of the organization of public transport mainly in Poland (described in the articles of mainly Polish scientists), but against the background of global research. At the end of it, it should be stated that public transport is most often understood as public transport, i.e. subsidized transport services carried out by using buses, trolleybuses, trams, subway, or city railways. There are many problems in this area that can be solved with mathematical modelling tools.

In the area of the functioning of public transport, there are basic areas that can be solved by using optimization methods and tools. The most important aspects are the shaping of the transport offer and the construction of the timetable. Preparing the route of communication lines and tracing vehicles in a network that has a certain size is troublesome and sometimes even impossible for a man who is not assisted by a computer. The use of IT tools equipped with applications that have an optimization engine reduces the possibility of making a mistake and it reduces operating costs.

The problem of assigning lines to service individual stops at intermodal interchanges is also important. Excessive stops may lead to a poor solution being chosen. A large group of problems concerns the planning of the work of vehicles (the allocation of vehicles for tasks) and the work of vehicle service teams (the allocation of human resources to tasks). These two problems have a very large impact on the financial functioning of the employing enterprise. Optimization tools allow you to reduce costs by allocating the least possible number of vehicles and people to handle transport tasks.

Research areas and mathematical tools specification is related to the scope of work on the POIR.01.01.01-000070/17-00 project Computer system for computer aided planning of public transport financed by the National Centre for Research and Development. We could only show selected methods due to the confidentiality agreement signed with the company with which we implement the project. To summarize - only part of the methods, which were used globally to solve the optimization problems of public transport functioning, were used in Poland. It is therefore reasonable to carry out the work on the project and use these methods to improve the situation in Poland.

The scientific work carried out as part of the POIR.01.01.01-00-0070/17-00 project Computer system for computer aided planning of public transport was financed by the National Centre for Research and Development.

\section{Notice}

The paper will be presented at MOTSP 2020 International Conference Management of Technology - Step to Sustainable Production, which will take place from $30^{\text {th }}$ September $-2^{\text {nd }}$ October 2020 in Bol, island Brač (Croatia). The paper will not be published anywhere else.

\section{REFERENCES}

[1] Gramza, G. (2011). Wybrane zagadnienia oceny jakości miejskiego publicznego transportu zbiorowego. Autobusy: technika, eksploatacja, systemy transportowe, 12, 128-134.

[2] Jackiewicz, J., Barcik, J., \& Czech, P. (2010). Standardy jakości usług w komunikacji miejskiej - część I. Zeszyty Naukowe. Transport/Politechnika Ślaska, 55-65.

[3] Jackiewicz, J., Czech, P., \& Barcik, J. (2010). Standardy jakości usług w komunikacji miejskiej. Cz. 2. Zeszyty Naukowe. Transport/Politechnika Śląska, (68), 73-82.

[4] Rudnicki, A. (1999). Jakość komunikacji miejskiej. Zeszyty Naukowo-Techniczne Oddziału Stowarzyszenia inżynierów i Techników Komunikacji w Krakowie, (71).

[5] Starowicz, W. (2004). Charakterystyka polskiej normy" Jakość usług w publicznym transporcie pasażerskim". TTS Technika Transportu Szynowego, 11(9), 29-41.

[6] Starowicz, W. (2007). Jakość przewozów w miejskim transporcie zbiorowym. Wydawnictwo Politechniki Krakowskiej, Kraków.

[7] Starowicz W. (2001). Kształtowanie jakości usług przewozowych w miejskim transporcie zbiorowym. Wydawnictwo Naukowe Uniwersytetu Szczecińskiego, Szczecin.

[8] Świderski, A. (2011). Modelowanie oceny jakości usług transportowych. Prace Naukowe Politechniki Warszawskiej. Transport, 3-160.

[9] Ustawa z dnia 16 grudnia 2010 r. o publicznym transporcie zbiorowym. Dz.U. 2011 nr 5 poz. 13 z późn. zm.

[10] Słownik języka polskiego PWN. See: https://sjp.pwn.pl/

[11] Madej, B., Pruciak, K., \& Madej, R. (2015). Publiczny transport drogowy. Zasady tworzenia rozkładów jazdy w komunikacji lokalnej (miejskiej i aglomeracyjnej). Warszawa.

[12] Żak, J. \& Jacyna-Gołda, I. (2013). Using queue theory to analysis and evaluation of the logistics centre workload. Archives of Transport, 25.

[13] Delling, D., Katz, B., \& Pajor, T. (2012). Parallel computation of best connections in public transportation networks. Journal of Experimental Algorithmics (JEA), 17, 4-1. https://doi.org/10.1145/2133803.2345678

[14] Drabicki, A., Kucharski, R., \& Szarata, A. (2017). Modelling the public transport capacity constraints' impact on passenger path choices in transit assignment models. Archives of Transport, 43. https://doi.org/10.5604/01.3001.0010.4224

[15] Izdebski, M. (2014). The use of heuristic algorithms to optimize the transport issues on the example of municipal services companies. Archives of Transport, 29. https://doi.org/10.5604/08669546.1146961

[16] Cai, Z. \& Yan, J. (2018). Analysis of residents' travel characteristics along Beijing rail transit line based on binary choice model. Archives of Transport, 47. https://doi.org/10.5604/01.3001.0012.6504

[17] Chamier-Gliszczyński, N. (2016). Model mobilności użytkowników miast dla potrzeb działań transportowych. Transport Miejski i Regionalny, 6.

[18] Juhász, M., Mátrai, T., \& Koren, C. (2017). Forecasting travel time reliability in urban road transport. Archives of Transport, 43. https://doi.org/10.5604/01.3001.0010.4227

[19] Oziomek, J. \& Rogowski, A. (2017). Wybrane metody poszukiwania rozwiązania problemu synchronizacji interwałowej. Autobusy: technika, eksploatacja, systemy transportowe, 18.

[20] Ullrich, O., Lückerath, D., Franz, S., \& Speckenmeyer, E. (2012). Simulation and optimization of Cologne's tram 
schedule. Simulation Notes Europe (SNE), ARGESIM/ASIM Pub., TU Vienna, 22(2), 69-76. https://doi.org/10.11128/sne.22.tn.10123

[21] Jacyna, M., Gołębiowski, P., \& Urbaniak, M. (2016, March). Multi-option model of railway traffic organization including the energy recuperation. In International Conference on Transport Systems Telematics, Springer, Cham, 199-210. https://doi.org/10.1007/978-3-319-49646-7_17

[22] Jacyna, M. \& Gołębiowski, P. (2015). Traffic organization on the railway network and problem of construction of graphic train timetable. Journal of KONES, 22. https://doi.org/10.5604/12314005.1165399

[23] Żurkowski, A. (2017). Nowoczesne rodzaje wykresów ruchu w zastosowaniu do przewozów aglomeracyjnych. Prace Naukowe Politechniki Warszawskiej. Transport.

[24] Jacyna, M., Gołębiowski, P., \& Pyza, D. (2018). Railway traffic organization model considering allocation of platform edges for passenger trains. Archives of Transport System Telematics, 11.

[25] Oziomek, J. \& Rogowski, A. (2016). Optymalny przydział autobusów do pozamiejskich linii komunikacyjnych w Ostrowcu Świętokrzyskim. Autobusy: technika, eksploatacja, systemy transportowe, 17(4), 14-19.

[26] Vannieuwenhuyse, B., Gelders, L., \& Pintelon, L. (2003). An online decision support system for transportation mode choice. Logistics Information Management. https://doi.org/10.1108/09576050310467269

[27] Sawicki, P. \& Fierek, S. (2017, September). Mixed Public Transport Lines Construction and Vehicle's Depots Location Problems. In Scientific and Technical Conference Transport Systems Theory and Practice, Springer, Cham, 213-224. https://doi.org/10.1007/978-3-319-64084-6_20

[28] Sawicki, P. \& Fierek, S. (2017). Problem jednoczesnego wyznaczania przebiegu linii i lokalizacji zajezdni w systemie transportu zbiorowego. Prace Naukowe Politechniki Warszawskiej-Transport, 119, 429-444.

[29] Giannopoulos, G. A. (2004). The application of information and communication technologies in transport. European journal of operational research, 152(2), 302-320. https://doi.org/10.1016/S0377-2217(03)00026-2

[30] Manerowski, J. \& Lubiecka-Budzanowska, M. (2014). Model matematyczny jakości transportu pasażerów w układzie aglomeracja-lotnisko. Prace Naukowe Politechniki Warszawskiej. Transport, (103), 157-167.

[31] Świderski, A. (2013). Modelowanie neuronowe w zastosowaniu do oceny jakości w logistyce. Gospodarka Materiałowa i Logistyka, (5 (CD)), 619-629.

[32] Fierek, S., Szarata, A., \& Żak, J. (2012). Wykorzystanie symulacyjnych modeli podróży i wielokryterialnej metody rankingowej do projektowania rozbudowy sieci tramwajowej. Zeszyty Naukowo-Techniczne Stowarzyszenia Inżynierów i Techników Komunikacji w Krakowie. Seria: Materiaty Konferencyjne.

[33] Tudela, A., Akiki, N., \& Cisternas, R. (2006). Comparing the output of cost benefit and multi-criteria analysis: An application to urban transport investments. Transportation Research Part A: Policy and Practice, 40(5), 414-423. https://doi.org/10.1016/j.tra.2005.08.002

[34] Geurs, K., Zondag, B., De Jong, G., \& de Bok, M. (2010). Accessibility appraisal of land-use/transport policy strategies: More than just adding up travel-time savings. Transportation Research Part D: Transport and Environment, 15(7), 382-393. https://doi.org/10.1016/j.trd.2010.04.006

[35] Kiciński, M. \& Solecka, K. (2018). Application of MCDA/MCDM methods for an integrated urban public transportation system-case study, city of Cracow. Archives of Transport, 46. https://doi.org/10.5604/01.3001.0012.2107

[36] Bauer, M. (2004). Założenia symulacyjnego modelu punktualności autobusów komunikacji miejskiej. Zeszyty Naukowe. Budownictwo/Politechnika Śląska, 83-90.

[37] Sobota, A. \& Żochowska, R. (2008). Model of urban public transport network for the analysis of punctuality. Journal of Achievements in Materials and Manufacturing Engineering, 28(1), 63-66.

[38] Grzelec, K. \& Miloch, M. (2017). Modelowanie podróży z przesiadkami w transporcie miejskim. Transport Miejski i Regionalny.

[39] Kisielewski, P. \& Talarek, P. (2017). Badania symulacyjne wybranego węzła komunikacyjnego dużego miasta. Symulacja w Badaniach i Rozwoju, 8(1-2).

[40] Naumov, V. (2016). Oszacowanie optymalnej liczby autobusów dla linii komunikacji miejskiej na podstawie symulacji komputerowych. Autobusy: technika, eksploatacja, systemy transportowe, 17.

[41] Żurkowski, A. (2009). Modelowanie przewozów międzyaglomeracyjnych. Problemy kolejnictwa, 5-47.

[42] Kruszyna, M. (1998). Wpływ organizacji ruchu na straty czasu pojazdów komunikacji zbiorowej. Zeszyty NaukowoTechniczne Oddziału Stowarzyszenia Inżynierów i Techników Komunikacji w Krakowie. Materiały Konferencyjne (nr 12), (64), 121-131.

[43] Karoń, G., Janecki, R., \& Sobota, A. (2010). Modelowanie ruchu w konurbacji górnośląskiej - sieć publicznego transportu zbiorowego. Zeszyty Naukowe. Transport/Politechnika Śląska, 35-42.

[44] Jacyna-Gołda, I., Gołębiowski, P., Izdebski, M., Kłodawski, M., Jachimowski, R., \& Szczepański, E. (2017). The evaluation of the sustainable transport system development with the scenario analyses procedure. Journal of Vibroengineering, 19(7), 5627-5638. https://doi.org/10.21595/jve.2017.19275

[45] Szarata, A. (2015). Metodyka badań strategicznych wariantów rozwoju systemu transportu zbiorowego w obszarach zurbanizowanych. Transport Miejski i Regionalny.

[46] Jacyna, M. \& Wasiak, M. (2014). Modelowanie podziału zadań przewozowych w segmencie przewozów pasażerskich. Zeszyty Naukowo-Techniczne Stowarzyszenia Inżynierów i Techników Komunikacji w Krakowie. Seria: Materiaty Konferencyjne.

[47] Jastrzębski, W. (2014). Dylematy i błędy w modelach i prognozach ruchu. Zeszyty Naukowo-Techniczne Stowarzyszenia Inżynierów i Techników Komunikacji w Krakowie. Seria: Materiaty Konferencyjne.

[48] Gołębiowski, P. \& Jacyna, M. (2017). The concept of computer application supporting the work of the organizers of railway transport and railway undertakings in the construction of trains timetable. In: CLC 2016: Carpathian Logistics Congress Congress Proceedings (CD-ROM). Edition $1^{\text {st }}$. Ostrava: Tanger Ltd., 534-539.

[49] Kisielewski, P. (2016). Nowoczesna platforma projektowa $\mathrm{i}$ integracyjna systemów IT $\mathrm{w}$ komunikacji miejskiej. Transport Miejski i Regionalny.

[50] Kisielewski, P. (2017). Wspomaganie logistyki transportu miejskiego z wykorzystaniem techniki informatycznej. Prace Naukowe Transport, (115).

[51] Masłowski, D., Kulińska, E., Wojtynek, L., \& DenderaGruszka, M. (2017). Analiza rozwiązań informatycznych wykorzystywanych $\mathrm{w}$ procesie planowania przejazdów komunikacji miejskiej. Autobusy: technika, eksploatacja, systemy transportowe, 18. 
[52] Ernst, A. T., Jiang, H., Krishnamoorthy, M., Owens, B., \& Sier, D. (2004). An annotated bibliography of personnel scheduling and rostering. Annals of Operations Research, 127(1-4), 21144. https://doi.org/10.1023/B:ANOR.0000019087.46656.e2

[53] Freling, R., Wagelmans, A. P., \& Paixão, J. M. P. (1999). An overview of models and techniques for integrating vehicle and crew scheduling. In Computer-aided transit scheduling, Springer, Berlin, Heidelberg, 441-460. https://doi.org/10.1007/978-3-642-85970-0_21

[54] Rekik, M., Cordeau, J. F., \& Soumis, F. (2004). Using benders decomposition to implicitly model tour scheduling. Annals of Operations Research, 128(1-4), 111-133. https://doi.org/10.1023/B:ANOR.0000019101.29692.2c

[55] Poliac, M. O., Lee, E. B., Slagle, J. R., \& Wick, M. R. (1987). A crew scheduling problem. In IEEE First International Conference on Neural Networks (Vol. 4, p. 779).

[56] Pedrosa, D. \& Constantino, M. (2001). Days-off scheduling in public transport companies. In Computer-Aided Scheduling of Public Transport, Springer, Berlin, Heidelberg, 215-232. https://doi.org/10.1007/978-3-642-56423-9_13

[57] Koutsopoulos, H. N. \& Wilson, N. H. (1987). Operator workforce planning in the transit industry. Transportation Research Part A: General, 21(2), 127-138. https://doi.org/10.1016/0191-2607(87)90005-7

[58] Belletti, R., Davini, A., Carraresi, P., \& Gallo, G. (1985). BDROP: A package for the bus drivers' rostering problem. From the book computer scheduling of public transport 2 .

[59] Jachnik, J. K. (1981). Attendance and rostering systems. Computer Scheduling of Public Transport, 337-343.

[60] Fores, S., Proll, L., \& Wren, A. (2001). Experiences with a flexible driver scheduler. In Computer-Aided Scheduling of Public Transport, Springer, Berlin, Heidelberg, 137-152. https://doi.org/10.1007/978-3-642-56423-9_8

[61] Hung, R. (1993). A three-day workweek multiple-shift scheduling model. Journal of the Operational Research Society, 44(2), 141-146. https://doi.org/10.1057/jors.1993.26

[62] Jacyna, M., Izdebski, M., Szczepański, E., \& Gołda, P. (2018). The task assignment of vehicles for a production company. Symmetry, 10(11), 551. https://doi.org/10.3390/sym10110551

[63] Lau, H. C. (1994). Manpower scheduling with shift change constraints. In International Symposium on Algorithms and Computation. Springer, Berlin, Heidelberg, 616-624. https://doi.org/10.1007/3-540-58325-4_230

[64] Tykulsker, R. J., O'neil, K. K., Ceder, A. A., \& Sheffi, Y. (1985). A commuter rail crew assignment/work rules model. From the book computer scheduling of public transport 2 .

[65] Izdebski, M., Jacyna-Gołda, I., Markowska, K., \& Murawski, J. (2017). Heuristic algorithms applied to the problems of servicing actors in supply chains. Archives of Transport, 44. https://doi.org/10.5604/01.3001.0010.6159
Authors' contacts:

Piotr Golębiowski, $\mathrm{PhD}$

(Corresponding author)

Warsaw University of Technology,

Faculty of Transport,

Koszykowa 75, 00662 Warsaw, Poland

Tel. +48 22 234-14-11, e-mail: pgolebiowski@wt.pw.edu.pl

Jolanta Żak, Prof.

Warsaw University of Technology,

Faculty of Transport,

Koszykowa 75, 00662 Warsaw, Poland

Tel. +48 22 234-14-43, e-mail: j.zak@wt.pw.edu.pl

Piotr Kisielewski, Prof.

Cracow University of Technology,

Faculty of Mechanical Engineering,

Jana Pawla II 37, 31864 Cracow, Poland

Tel. +48 12 374-33-12, e-mail: pkisielewski@pk.edu.pl 